\title{
PREVALENCE OF REPRODUCTIVE DISEASES AND ITS ASSOCIATED RISK FACTORS IN CROSSBRED DAIRY COWS
}

\author{
Md. Atikul Alam¹, Md. Musharraf Uddin Bhuiyan ${ }^{1 *}$, Mst. Sonia Parvin², \\ Mohammad Moshiur Rahman ${ }^{1}$ and Farida Yeasmin Bari ${ }^{1}$
}

${ }^{1}$ Department of Surgery and Obstetrics, and ${ }^{2}$ Department of Medicine, Faculty of Veterinary Science, Bangladesh Agricultural University, Mymensingh-2202, Bangladesh

*Corresponding author: Md. Musharraf Uddin Bhuiyan, E-mail: mmubhuiyan@gmail.com

\section{ARTICLE INFO}

Received

29.09.2014

Accepted

27.10.2014

Online

27.12.2014

Key words:

Prevalence

Dairy cow

Risk factors

Reproductive

diseases

\section{ABSTRACT}

Reproductive diseases of crossbred dairy cows significantly reduce productivity which is of great concern of dairy producers worldwide. The objectives of this study were to determine the prevalence of reproductive diseases and its associated risk factors in crossbred dairy cows in selected areas of Bangladesh. The study was conducted at eight villages of Ullapara Upazila under Sirajganj district. A total of 197 dairy farms having 488 breedable crossbred dairy cows (395 cows + 93 heifers) were randomly selected. A questionnaire as well as examination of cows was made to collect data on occurrence of reproductive diseases. The overall prevalence of reproductive diseases was 39.4\%. Among the diseases, post calving anoestrus was $8.6 \%$, delayed puberty was $6.8 \%$, repeat breeding was $5.7 \%$, retained placenta was $4.7 \%$, metritis was $3.9 \%$, dystocia was $3.3 \%$, vaginal prolapse was $2.7 \%$, abortion was $2.1 \%$ and uterine prolapse was $1.6 \%$. The body condition score (BCS) of cows significantly $(P<0.05)$ influenced the occurrence of reproductive disease. However, feeding practice, suckling, milk yield and parity did not influence significantly $(P>0.05)$ the occurrence of reproductive diseases in crossbred dairy cows. In conclusion, further studies are needed with more number of cows to confirm the findings.

To cite this article: MA Alam, MMU Bhuiyan, MS Parvin, MM Rahman and FY Bari, 2014. Prevalence of reproductive diseases and its associated risk factors in crossbred dairy cows. Res. Agric., Livest. Fish. 1(1): 71-79.

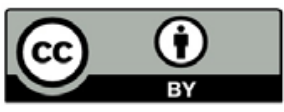

This article is an open access article licensed under the terms of the Creative Commons Attribution License.

www.agroaid-bd.org/ralf, e-mail: editor.ralf@gmail.com 


\section{INTRODUCTION}

Livestock is an integral part of agriculture in Bangladesh. About $80 \%$ of our population is directly or indirectly involved in agriculture and livestock farming. The contribution of livestock in Gross Domestic Product (GDP) is about $2.51 \%$ in Bangladesh (BBS, 2012). The urban and rural society of Bangladesh has long been enjoying the contribution of livestock for meeting the demand of nutrition and livelihood as an agricultural dependent country. Total cattle population of this country is about 24.5 million, which is about $1.79 \%$ of the world and $5.47 \%$ of Asia's cattle population (FAO, 2004). Despite the huge number of cattle population in Bangladesh, the economic benefit from cattle rearing is very low due to the constraints of disease, nutrition, poor management and poor genetics of animals. These constraints result in poor reproductive performances of dairy cattle in Bangladesh. Artificial insemination using semen of exotic breed has been in practice for long time to genetically upgrade the local cows of Bangladesh. However, crossbred cows suffer more from reproductive problems than local cows (Faruq, 2001).

It is well established that maintaining a satisfactory fertility level is the fundamental aspect for successful operation of any cattle breeding program as the economy of dairy farming largely depends on optimum pregnancy rate after insemination. The twelve-month calving interval is advantageous for maximal milk yield per cow per year with good economic return (Opsomer et al., 1996). However, one of the major constraints of profitable dairy farming in Bangladesh is low conception rate (Alam and Ghosh, 1994). Moreover, genital infections, either specific or nonspecific in nature, may account for large number of pregnancy failure in cows (Sirohi et al., 1989). As a result, a large number of animals remain barren or unproductive having exposed many times for natural mating or artificial insemination and become a burden for the farmers around the year.

To make the farm profitable, it is essential to know the pattern of occurrence of reproductive diseases in crossbred cows including risk factors influencing those diseases. This will definitely help farmers to reduce the occurrence of such diseases resulting in economically viable dairy industry in Bangladesh. Accordingly, Shamsuddin (1988) studied the occurrence reproductive diseases in large government dairy farm and identified retained placenta, metritis, pyometra, endometritis, cervicitis, persistent corpora lutea, cystic ovaries and non functional ovaries as major reproductive diseases in Bangladesh. However, very limited studies have been conducted to determine the prevalence of reproductive diseases in crossbred cows of small holding farms in Bangladesh (Maruf, 2012). Moreover, it is likely that occurrence of reproductive diseases in dairy cows may be influenced, among others, by body condition score, feeding practices, suckling, milk yield and parity.

Considering the above mentioned facts, the present study was conducted to investigate the prevalence of reproductive diseases and its associated risk factors in crossbred dairy cows in selected area of Bangladesh.

\section{MATERIALS AND METHODS}

\section{Study areas and population}

A total of 197 dairy farms having 488 crossbred dairy cows (395 cows +93 heifers) were randomly selected in eight villages of Ullapara Upazila under Sirajganj district during the period from December 2012 to April 2013. The villages were Mohonpur, Aliapur, Vangri, Changtia, Dharail, Nandakusha, Mordoho and Boyra where Community-based Dairy Veterinary Foundation (CDVF), Bangladesh Agricultural University, Mymensingh has been providing services to the farms. 


\section{Management of cows}

Farmers housed their cows in traditional houses. Most cows were fed with straw, green grass and little concentrate with free access to water. Farmers practice routine deworming and vaccination against FMD and Anthrax. The cows are milked by hand milking keeping calves at feet of the cows.

\section{Data collection}

A questionnaire was prepared according to the objectives of the investigation and was designed in a simple way so that the farmers could understand easily. The questionnaire included questions to collect information of age, breed, BCS, respiration, pulse, temperature, feeding practices, reproductive diseases, other diseases, age at puberty (month), parity, last calving date, service needed for previous pregnancy, date of first service after last parturition, date of last service, type of service, pregnancy period (month), service needed for present conception, number of service given, problem at last pregnancy, problem at parturition, suckling and milk yield. The data were collected directly from owner of dairy farms by interviewing, by examination of records, if any, and by examination of animals and sheds. Information was collected on all breedable animals (cows that calved 60 or more days before but did not conceive and heifers those are 24 or more months old but were not pregnant) and pregnant cows. Cows seemed to suffer from delayed puberty, repeat breeding, post-calving anoestrus and metritis was examined by per rectal palpation of genital tracts to confirm the diagnosis.

\section{RESULTS}

A total of 197 dairy farms having 488 breedable cows and heifers were examined for determination of occurrence of different reproductive diseases and to identify the associated risk factors influencing them. Post-calving anoestrus, delayed puberty, repeat breeding, retained placenta, metritis, dystocia, vaginal prolapse, abortion and uterine prolapse were the major reproductive problems.

\section{General health information}

The mean age of cows was $5.3 \pm 2.2$ years, mean BCS was $2.5 \pm 0.3$, mean respiration rate was $20.3 \pm 2.6$ per minute, mean pulse rate was $68.8 \pm 4.2$ per minute and mean temperature was $101.8 \pm 0.8^{\circ} \mathrm{F}$ (Table 1 ).

Table 1. General health information of crossbred dairy cows in Sirajgonj

\begin{tabular}{|lll|}
\hline Total number of cows examined & Cows parameters & Mean \pm SD \\
\hline & & \\
\hline \multirow{4}{*}{488} & Age (Years) & $5.3 \pm 2.2$ \\
& BCS & $2.5 \pm 0.3$ \\
& Respiration (per min) & $20.3 \pm 2.6$ \\
& Pulse (per min) & $68.8 \pm 4.2$ \\
& Temperature $\left({ }^{\circ} \mathrm{F}\right)$ & $101.8 \pm 0.8$ \\
\hline
\end{tabular}

\section{Occurrence of different reproductive diseases or disorders}

Prevalence of reproductive diseases or disorders was $39.4 \%$ in total population. Among the diseases, post calving anoestrus was $8.6 \%$, delayed puberty was $6.8 \%$, repeat breeding was $5.7 \%$, retained placenta was $4.7 \%$, metritis was $3.9 \%$, dystocia was $3.3 \%$, vaginal prolapse was $2.7 \%$, abortion was $2.1 \%$ and uterine prolapse was $1.6 \%$ (Table 2 ). 


\section{Effects of BCS on occurrence of reproductive diseases}

The highest occurrence of reproductive diseases was recorded in cows with BCS $\leq 2(49.3 \%)$ and the lowest occurrence was in cows with BCS $\geq 3(27.9 \%)$ (Table 3$)$. The variation in disease occurrence among cows with different BCS groups was significant $(P<0.05)$.

\section{Effects of feeding practices on occurrence of reproductive diseases}

The highest occurrence of reproductive diseases was recorded in cows fed with straw + green grass $(45.3 \%)$ and the lowest occurrence was in cows fed with straw + green grass + concentrates $(30.4 \%)$ (Table 3). The variation in disease occurrence among cows with different feeding groups was not significant $(P>0.05)$.

\section{Effects of suckling on occurrence of reproductive diseases in crossbred dairy cows}

The highest occurrence of reproductive diseases was recorded in cows suckled several times daily $(43.2 \%)$ and the lowest occurrence was in cows having no suckling $(34.7 \%)$ (Table 3$)$. The variation in disease occurrence among cows with different suckling groups was not significant $(\mathrm{P}>0.05)$.

Table 2. Prevalence of reproductive diseases in crossbred dairy cows

\begin{tabular}{|llll|}
\hline $\begin{array}{l}\text { Total number of cows } \\
\text { examined }\end{array}$ & Diseases/Disorders found & $\begin{array}{l}\text { No. of affected } \\
\text { cows }\end{array}$ & $\begin{array}{l}\text { \% of disease } \\
\text { occurrence }\end{array}$ \\
\hline \multirow{4}{*}{488} & Post calving anoestrus & 42 & 8.6 \\
& Delayed puberty & 33 & 6.8 \\
& Repeat breeding & 28 & 5.7 \\
& Retained placenta & 23 & 4.7 \\
& Metritis & 19 & 3.9 \\
& Dystocia & 16 & 3.3 \\
& Vaginal prolapse & 13 & 2.7 \\
& Abortion & 10 & 2.1 \\
& Uterine prolapse & 8 & 1.6 \\
& Total & $\mathbf{1 9 2}$ & $\mathbf{3 9 . 4}$ \\
\hline
\end{tabular}

Effects of milk yield on occurrence of reproductive diseases in crossbred dairy cows

The highest occurrence of reproductive diseases was recorded in cows yielded $>10-14$ liters milk daily (46.9\%) and the lowest occurrence was in cows yielded $>5-10$ liters milk daily $(32.9 \%)$ (Table 3). The variation in disease occurrence among cows with different daily milk yield groups was not significant $(P>0.05)$.

\section{Effects of parity on occurrence of reproductive diseases in crossbred dairy cows}

The highest occurrence of reproductive diseases was recorded in cows at $4^{\text {th }}$ to $8^{\text {th }}$ parity $(43.2 \%)$ and the lowest occurrence was in cows with $2^{\text {nd }}$ to $3^{\text {rd }}$ parity $(33.7 \%)$ (Table 3$)$. The variation in disease occurrence among cows with different parity groups was not significant $(P>0.05)$.

\section{DISCUSSION}

The purpose of this study was to investigate overall prevalence of reproductive diseases and its associated risk factors in crossbred dairy cows in Ullapara Upazila under Sirajganj district. Considering the general health parameters of the animals such as respiration rate, pulse rate and body temperature, the investigated cows can be regarded as healthy. 
Table 3. Effects of BCS, type of feed, suckling, milk yield and parity on occurrence of reproductive diseases in crossbred dairy cows

\begin{tabular}{|llll|}
\hline Parameters & $\begin{array}{l}\text { No. of cows } \\
\text { examined }\end{array}$ & $\begin{array}{l}\text { No. of diseased } \\
\text { cows }\end{array}$ & Occurrence (\%) \\
\hline BCS & & & \\
$\leq 2$ & 136 & 67 & $49.3^{\mathrm{a}}$ \\
2.5 & 248 & 96 & $38.7^{\mathrm{a}}$ \\
$\geq 3$ & 104 & 29 & $27.9^{\mathrm{b}}$ \\
Type of feed & & & \\
$\quad$ Straw + Green Grass & 232 & 105 & 45.3 \\
Straw + Concentrates & 177 & 63 & 35.6 \\
Straw + Green Grass + & 79 & 24 & 30.4 \\
Concentrates & & & \\
Suckling & 76 & 33 & 43.2 \\
$\quad$ Several times & 161 & 64 & 39.8 \\
Twice & 135 & 47 & 34.8 \\
Once & 23 & 8 & 34.7 \\
$\quad$ No suckling & & & 41.0 \\
Milk yield ( liters) & 217 & 89 & 32.9 \\
2-5 & 146 & 48 & 46.9 \\
$>5-10$ & 32 & 15 & 42.3 \\
$>10-14$ & & & 33.7 \\
Parity & 123 & 52 & 43.2 \\
$\quad 1^{\text {st }}$ & 184 & 62 & \\
$2^{\text {nd }}$ to $3^{\text {rd }}$ & 88 & 38 & \\
$4^{\text {th }}$ to $8^{\text {th }}$ & & & \\
\hline
\end{tabular}

abPercentage values with superscript within same column differed significantly from each other $(p<0.05)$

The present study indicates the overall prevalence of reproductive diseases or disorders in crossbred dairy cows was $39.4 \%$. Similar prevalence of reproductive diseases (38.6\%) in HF pure breed cows was reported at Sinjai Regency, Indonesia (Yusuf et al., 2012). Contrasting to the present finding, $23.0 \%$ prevalence of reproductive diseases was reported in crossbred cows in Chittagong district (Maruf, 2012). Moreover, 36.5\% prevalence of reproductive diseases was observed in Holstein x Gir Fl crossbred cows in Tanzania (Kaikini et al., 1983). The variation in prevalence of reproductive diseases in cows among studies may be due to variation in management of cows and agro-climatic condition of areas.

In the present study, the BCS significantly influenced the occurrence of reproductive diseases in crossbred dairy cows. The lowest occurrence of reproductive diseases in cows with high BCS and the highest occurrence of reproductive diseases in cows with low BCS. In line with the present finding, influence of BCS on occurrence of various reproductive diseases was also reported elsewhere (Shamsuddin et al., 2006). The authors reported that cows with lower BCS had longer intervals from calving to first ovulation and less detected estrus. Similar reports are available on postpartum cows brought for first service (Siddiqui, 2008). Low body energy reserves of cows greatly increase the probability of suffering from metabolic disorders, reproductive failure, reduction in milk yield and delayed puberty (Montiel and Ahuja, 2005). Moreover, cows with low BCS may have poor quality oocytes, which do not fertilize normally. Even if fertilized, oocytes of poor BCS cows often do not sustain development to term (Siddiqui et al., 2002). 
In this study, feeding practices did not significantly affect the occurrence of reproductive diseases in crossbred cows as indicated by presence of no significant difference in disease occurrence among different feeding practice groups although numerically higher occurrence was observed in cows received straw and green grass than that of straw, green grass and concentrate. Nutrition has long been known to have a profound influence on reproductive performance of female cattle (Shamsuddin et al., 2010). Accordingly, lack of energy has been proved to adversely affect the size and ovulatory fate of the dominant follicle (Diskin et al., 2003). Moreover, prolonged deficiency of energy and protein in the diet can exert chronic stress on the hypothalamo-pituitaryovarian axis. As a result, affected cows and heifers not only delay ovarian cyclicity, but also have poor heat symptoms, which make oestrus detection and timing of breeding difficult for the farmer and inseminator, which will have negative effects on conception rate (Siddiqui et al., 2002). The farmers usually provide better feeding through supplementation of concentrate by-products such as oil cakes, wheat bran and pulse bran. However, due to lack of available grazing lands, sometimes cattle are tethered on the roadsides and fallow land. Seasonal and fluctuating supply of rice straw and green grass also creates a great problem in feeding dairy cattle (Rahman et al., 1998).

In the present study, suckling did not significantly affect the occurrence of reproductive diseases in crossbred cows as indicated by presence of no significant difference in disease occurrence among different suckling groups although numerically higher occurrence was observed in cows suckled several times than that of no suckling counterpart. Generally suckling is not controlled in dairy production system in Bangladesh. The adverse effects of the duration and frequency of suckling on the initiation of post-partum cyclicity was studied by Shamsuddin et al. (2006) and they reported that frequent suckling increased the interval from calving to first service and to conception. Moreover, partial or restricted suckling reduced the postpartum anoestrous period and improved pregnancy rates elsewhere (Montoni and Riggs, 1978). This can be explained by the fact that suckling tends to suppress growth of follicles (Carter et al., 1980) and blocks ovulation (Spicer and Echternkamp, 1986). Moreover, the frequency and amplitude of LH peaks, together with reduced sensitivity of the pituitary to LH-releasing hormone may be the cause of inhibition of ovulation in suckled cows (Carruthers et al., 1980).

In the present study the highest occurrence of reproductive diseases was recorded in cows yielded $>10-14$ liters milk daily and the lowest occurrence was in cows yielded $>5-10$ liters milk daily although the difference was not significant. The major goal of the dairy industry is to provide milk for the consumer market. Over the past several decades, milk yield of cows has increased markedly. However, one negative impact of this improvement is reduced fertility (Dhaliwal et al., 1996). High milk production and imbalanced feeding are the factors for reproductive disorders in crossbred cows (Shamsuddin et al., 1988). The increase in milk production per cow has been accompanied by a significant increase in the calving interval. Both the average number of days open (interval from calving to the next conception) and the number of services per conception increase substantially, whereas the conception rate decline significantly in high yielding cows (Lucy, 2001). Moreover, several physiological consequences of increased milk production are early pregnancy losses, increased incidence of metabolic and reproductive diseases, intensified postpartum negative energy balance and reduced circulating concentrations of steroids (Lucy, 2001).

The present study showed the highest occurrence of reproductive diseases was recorded in cows at $4^{\text {th }}$ to $8^{\text {th }}$ parity and the lowest occurrence was in cows with $2^{\text {nd }}$ to $3^{\text {rd }}$ parity although the difference was not significant. Similar to present finding, the lowest occurrence of reproductive diseases was reported in 2 nd and 3 rd parity cows than that of $4^{\text {th }}$ to $7^{\text {th }}$ parity counterparts (Sawa et al., 2012). It is likely that first parity cows may have dystocia and older cows may have retained placenta and ovarian cysts (Grohn et al., 1990). Sardar et al. (2010) found higher incidence of metritis in $>8$ year old cows. Similarly Huffman (1984) reported higher incidence of pyometra in 
older cows. Usually, the risk of retained placenta, metabolic disorder and endometritis may increase with advancing parity.

\section{CONCLUSIONS}

In conclusion, the present study reveal that the overall prevalence of reproductive diseases in crossbred cows is $39.4 \%$. Major diagnosed reproductive diseases are post calving anoestrus, delayed puberty, repeat breeding, retained placenta, metritis, dystocia, vaginal prolapse, abortion and uterine prolapse. BCS of cows significantly influences the occurrence of reproductive disease. Feeding practice, suckling, milk yield and parity do not influence the occurrence of reproductive diseases. Further studies are needed with more number of cows to confirm the findings.

\section{COMPETING INTEREST}

The authors declare that they have no competing interests.

\section{REFERENCES}

1. Alam MGS and A Ghosh, 1994. Reproductive performance in cows: Its relationship to parity and season. Bangladesh Veterinary Journal, 22: 51-61.

2. Arthur GH, DE Noaks and H Pearson, 1989. Veterinary Reproduction and Obstetrics. $7^{\text {th }}$ edition. W.B. Saunders Company Limited London Philadephia Toronto Sydney Tokoyo, pp. 345-388.

3. BBS, 2012. Statistical year book of Bangladesh. $21^{\text {st }}$ Bangladesh bureau of statistics, government of Bangladesh, Bangladesh. Journal of the American Veterinary Medical Association, 41: 663-670.

4. Bhattachary H, DM Makhdoomi and A Hafiz, 2008. Prevalence of true anoestrus and delayed puberty in cattle. Indian Journal of Dairy Science, 18: 27-30.

5. Bitew M and S Prasad, 2010. Study on major reproductive health problems in indigenous and crossbred cows in and around Bedelle, south west Ethiopia. Journal of Animal and Veterinary Advances, 10: 723-727.

6. Carruthers TD, EM Convey, JS Kesner, HD Hafs and KW Cheng, 1980. The hypothalamo-pituitary gonadotrophin axis of suckled and nonsuckled dairy cows postpartum. Journal of Animal Science, 51: 949-957.

7. Carter MC, DJ Dierschke, JJ Rutledge and ER Hauser, 1980. Effect of GnRH and calf removal on pituitary ovarian function and reproductive performance in postpartum cows. Journal of Animal Science, 51: 903-904.

8. Correa MT, HN Erb and J Scarlett, 1993. Path analysis for seven postpartum disorders of Holstein cows. Journal of Dairy Science, 76: 1305-1312.

9. Dhaliwal GS, RD Murray and H Dobson, 1996. Effects of milk yield, and calving to first service interval,in determining herd fertility in dairy cows. Animal Reproduction Science, 41: 109-117.

10. Diskin MG, DR Mackey, JF Roche and Sreenan JM, 2003. Effects of nutrition and metabolic status on circulating hormones and ovarian follicle development in cattle. Animal Reproduction Science, 78: 345-370.

11. FAO, 2004. Selected Indicators of Food and Agriculture Development in Asia-Pacific Region, $1993-$ 2003. Food and Agriculture Organization of the United Nations, Bangkok, Thailand, pp. 119-121.

12. Faruq $\mathrm{BH}, 2001$. Clinical and abattoir studies on reproductive diseases of cows in Bangladesh. MS Thesis, submitted to the Department of Surgery and Obstetrics, Bangladesh Agricultural University, Mymensingh.

13. Francos C, 1974. Observation on the frequency of reproductive disorders in dairy herds in Israel. Deutsche Tierarzlliche Wochenschra, 81: 135-138.

14. Grohn YT, HN Erb, CE McCulloch and HS Saloniemi, 1990. Epidemiology of reproductive disorders in dairy cattle: Associations among host characteristics, disease and production. Preventive Veterinary Medicine, 8: 25-39. 
15. Huffman EM, 1984. Risk factors for prebreeding pyometra on four Colorado dairy farms. Preventive Veterinary Medicine, 2 (6): 785-790.

16. Kaikini AS, GK Chikalikar and CV Dindorkar, 1983. Reproductive disorders in Holstein X Gir F I crossbred cows. Indian Journal of Animal Science, 53: 556-558.

17. Kanuyaa NL, BM Kessy, SBP Bittegeko, NSY Mdoe and AAO Aboud, 2000. Suboptimal reproductive performance of dairy cattle kept in smallholder herds in a rural highland area of northern Tanzania. Preventive Veterinary Medicine, 45: 183-192.

18. Lucy MC, 2001. Reproductive loss in high-producing dairy cattle: where will it end? Journal of Dairy Science, 84: 1277-1293.

19. Mandali GC, PR Patel, AJ Dhami and SK Raval, 2004. Epidemiological surveillance on effect of housing, hygiene and nutritional status on periparturient disorders in buffaloes. Indian Journal of Dairy Science, 57: 132-136.

20. Maruf AA, 2012. Prevalence of reproductive disorders of crossbred cows in selected areas of the Chittagong district of Bangladesh. MS Thesis, submitted to the Department of Surgery and Obstetrics, Bangladesh Agricultural University, Mymensingh.

21. Montiel F and C Ahuja, 2005. Body condition and suckling as factors influencing the duration of postpartum anestrus in cattle: A review. Animal Reproduction Science, 85: 1-26.

22. Montoni $D$ and JK Riggs, 1978. Effect of restricted suckling on yields and reproductive performance in a Brahman herd. Agronomia Tropical, 28: 551-571.

23. Morrow DA, 1986. Current therapy in Theriogenoiogy: Diagnosis, treatment and prevention of reproductive diseases in animals. WB Soundars Company, Philadelphia, 48: 322-571.

24. Opsomer G, P Mijtem, M Coryn and AD Kruif, 1996. Postpartum anestrus in dairy cows, a review. Veterinary Quarterly, 18: 68-75.

25. Pals S, 2003. Investigation on health disorder in dairy cattle and buffaloes during pre and postpartum period. PhD. Thesis, submitted to NDRI, Karnal. Indian Journal of Science, 67: 661.

26. Rahman MM, S Akhtar and MM Hossain, 1998. The availability of livestock feeds and feeding practices followed by the farmer of some areas of Mymensingh District. Bangladesh Journal of Animal Science, 27: 119-126.

27. Saini MS, AS Khanna and SC Chopra, 1988. Incidence of retention of placenta, its treatment and subsequent fertility in crossbred dairy cattle. Indian Journal of Animal Production and Management, 4: 61-65.

28. Sardar MJU, MIJ Moni and S Aktar, 2010. Prevalence of reproductive disorder of crossbred cows in rajsahi district in Bangladesh. SAARC Journal of Agriculture, 8: 65-75.

29. Sawa A, M Bogucki and S Krezel-Czopek, 2012. Reproduction performance of cows with single, twin and triplet calves. Journal of the University of Veterinary and Pharmaceutical Sciences in Brno, Czech Republic, 8: 347-352.

30. Sethi RK and DS Balaine, 1978. An approach to quantification of threshold traits in dairy cattle. Indian Journal of Dairy Science, 48: 344-345.

31. Shamsuddin M, MGS Alam and JU Ahmed, 1988. Reproductive disorders of cross-bred cows. Bangladesh Veterinary Journal, 22: 21-28.

32. Shamsuddin M, J Bhattacharjee, WJ Goodger, H Momont, G Frank, AK Talukder and M Akteruzzaman, 2010. Community-based productivity veterinary service for smallholder dairy farmers in Bangladesh: In sustainable improvement of animal production and health. Food and Agriculture Organization of the United Nations, Rome, pp. 247-253.

33. Shamsuddin M, MMU Bhuiyan, PK Chanda, MGS Alam and D Galloway, 2006. Radioimmurnoassay of milk progesterone as a tool for fertility control in smallholder dairy fames. Tropical Animal Health and Production, 38: 85-92.

34. Sharma RN, BK Singh and MP Sinha, 1988. Non-specific infection on repeated conception failure. Indian Journal of Animal Reproduction, 9: 105.

35. Siddiqui MAR, 2008. Laboratory tests to predict bull fertility and the value of sperm nuclear shape analysis. PhD Thesis, Department of Surgery and Obstetrics, Bangladesh Agricultural University, Mymensingh, pp. 108-109.

36. Siddiqui MAR, M Shamsuddin, MMU Bhuiyan, MA Akbar and K Kamatuddin, 2002. Effect of feeding and body condition score on multiple ovulation and embryo production in zebu cows. Reproduction of Domestic Animal, 37: 37-41. 
37. Sirohi NS, DP Monga and SK Knar, 1989. Microbiological studies on some reproductive disorders of cattle. Indian Journal of Animal Sciences, 59: 537-541.

38. Spicer LJ and SE Echternkamp, 1986. Ovarian follicular growth, function and turnover in cattle: A review. Journal of Animal Science, 62: 428-451.

39. Vasconcelos JLM, S Sangsritavong, SJ Tsai and MC Wiltbank, 2003. Acute reduction in serum progesterone concentrations after feed intake in dairy cows. Theriogenology, 60: 795-807.

40. Yusuf M, L Rahim and N Aliah, 2012. The incidence of reproductive disorders in dairy herd: A case study in Sinjai Regency. Indonesia. Journal of Science and Technology Ranch, 2: 1-9. 